\title{
A Novel Colorimetric and Fluorescent Anion Chemosensor Based on the Flavone Quasi-crown Ether Metal Complex
}

\author{
Li-Li Zhou, Hao Sun, Hua-Ping Li, Hui Wang, Xiao-Hong Zhang,* \\ Shi-Kang $\mathbf{W u}$,* and Shuit-Tong Lee
}

Technical Institute of Physics and Chemistry, Chinese Academy of Sciences, Beijing, 100101, China

Institute of Functional Material Chemistry, Faculty of Chemistry, Northeast Normal University, Changchun, 130024, China

Center of Super-Diamond and Advanced Films, City University of Hong Kong, Hong Kong SAR, China

zhangxh8@yahoo.com

\section{Supporting information}

The detailed experimental procedures of ligand $\mathbf{L}$ 


\section{Experimental part}

\section{Instruments and reagents}

The proton NMR spectra were recorded at $300 \mathrm{MHz}$, Varian Gemin-300. And IR spectra were obtained on a Perkin-Elmer 938G spectrophotometer using KBr plate. Mass spectra were recorded on a Finnigan 4021C MS-spectrometer. All absorption and fluorescence spectra in this work were recorded in Hitachi U-3010 UV-Vis spectrometer and Hitachi F-4500 fluorescence spectrometer respectively. All chemicals used are analytical reagents. The solvents used for the reaction and measurements are purified prior to use. The solvent for the fluorescence measurement is purified until no disturbance detected.

The compounds studied here included ligands and complexes that can be dissolved in acetonitrile very well. All spectra and colorimetric testing are measured in acetonitrile.

All anionic compounds - the tetra-N-butyl ammonium salt of $\mathrm{F}^{-}, \mathrm{C} \mathrm{1}^{-}, \mathrm{Br}^{-}, \mathrm{I}^{-}$, $\mathrm{H}_{2} \mathrm{PO}_{4}^{-}, \mathrm{NO}_{2}^{-}, \mathrm{HSO}_{4}^{-}, \mathrm{HCO}_{3}^{-}, \mathrm{AcO}^{-}$anions - are purchased from Aldrich and used without further purification.

\section{Synthesis of the ligand compound}

Synthesis of ligand $\mathbf{L}$ was shown in scheme 3

\section{1,11-Dibromo-3, 6, 9-trioxaundecane}

A solution of tetra-glycol $(17.3 \mathrm{~mL})$ dissolved in dry ether $(30 \mathrm{~mL})$ was stirred in dry atmosphere and cooled down to $0^{\circ} \mathrm{C}$. Into the solution, $8.5 \mathrm{~mL}$ of phosphorous tri-bromide was added dropwise. The temperature of the solution was kept below $5^{\circ} \mathrm{C}$ in the process. After completion of addition, the solution was allowed to warm up to room temperature and stirred for 4 hours. Then, the reaction mixture was poured into a crushed ice bath, the separated organic layer was washed by water with $10 \%$ sodium carbonate. Product was dried by anhydrous potassium carbonate, then, the solvents were evaporated yielding a yellow liquid.

${ }^{1} \mathrm{NMR}\left(\mathrm{CDCl}_{3}\right): \quad \delta 3.4(\mathrm{t}, 4 \mathrm{H}), 3.63(\mathrm{~s}, 8 \mathrm{H}), 3.7 \sim 3.8(\mathrm{t}, 4 \mathrm{H}) . \quad \mathrm{IR}: \quad 2868 \mathrm{~cm}^{-1}\left(\mathrm{v}_{-\mathrm{CH} 2}\right)$, 
$1180 \mathrm{~cm}^{-1}\left(\mathrm{v}_{\mathrm{CH} 2-\mathrm{O}-\mathrm{CH} 2}\right)$.

\section{4'-Dimethylamino-2, 5-dihydroxychalcone ${ }^{[13]}$}

A mixture of 2,5-dihydroacetophenone $(3.04 \mathrm{~g}, 20 \mathrm{mmol})$, p-dimethylamino benzaldehyde $(4.47 \mathrm{~g}, 30 \mathrm{mmol})$, and $\mathrm{KOH}(30 \mathrm{~g})$ in methanol $(50 \mathrm{~mL})$ and water $(25 \mathrm{~mL})$ solution was stirred at room temperature for 24 hours. After mixing with $32 \mathrm{~g}$ acetic acid and $300 \mathrm{~mL}$ water, the obtained clear solution turned fresh red and a brown solid was precipitated. The brown solid was re-crystallized from $95 \%$ ethanol, then, 5.6g brown powders were obtained. Mp: $206 \sim 208^{\circ} \mathrm{C}$.

${ }^{1} \mathrm{HNMR}\left(\mathrm{DMSO}_{\mathrm{d}}\right): \quad \delta 3.0(\mathrm{~s}, 6 \mathrm{H}), 6.7 \sim 7.8(\mathrm{~m}, 9 \mathrm{H}), 9.2(\mathrm{~s}, 1 \mathrm{H}), 12.4(\mathrm{~s}, 1 \mathrm{H})$.

MS (m/e): $283(147,134,121,103,77,53)$.

\section{4'-Dimethylamino-2, 7-dihydroxyflavone}

$30 \%$ Hydrogen peroxide $(20 \mathrm{~mL})$ was added dropwise to a DMSO (50mL) solution of 4'-dimethylamino-2, 5-dihydroxychalcone $(5 \mathrm{~g}, 17.6 \mathrm{mmol})$ and $\mathrm{KOH}$ $(25 \mathrm{~mL}, 20 \%)$ at $0^{\circ} \mathrm{C}$. After stirring for 4 hours at room temperature, a blackish green solution was formed. Mixed the solution with glacial acetic acid and $300 \mathrm{~mL}$ water in a $500 \mathrm{~mL}$ beaker, a solid product was precipitated. After filtration, washing and re-crystallization by $95 \%$ ethanol, a yellow powder product was obtained. mp: $280 \sim 282^{\circ} \mathrm{C}$.

${ }^{1} \mathrm{HNMR}\left(\mathrm{CD}_{3} \mathrm{COCD}_{3}\right): \delta 3.05(\mathrm{~s}, 6 \mathrm{H}), 3.4(\mathrm{~m}, 2 \mathrm{H}), 6.8(\mathrm{~d}, 2 \mathrm{H}), 7.2 \sim 7.6(\mathrm{M}, 3 \mathrm{H}), 8.2$ $(\mathrm{d}, 2 \mathrm{H})$.

MS (m/e): 297 (268, 240, 149, 105, 89, 77, 52, 43).

\section{4 '-(Dimethylamino)-2,7-(3,6,9-trioxaundecane-1, 11-dioxy) flavone (L)}

Anhydrous sodium carbonate $(2 \mathrm{~g})$ and $200 \mathrm{~mL}$ of DMF were added into a dry three-neck round-bottom-flask with two capillary drop funnels and a reflux condenser. 1,11-dibromo-3, 6, 9-trioxaundecane $(2.8 \mathrm{~g}, 8.8 \mathrm{mmol})$ was dissolved in $80 \mathrm{ml}$ of DMF in one funnel, while 4'-dimethylamino-2, 7-dihydroxyflavone (1.3g, 8,8mmol) dissolved in $80 \mathrm{~mL}$ of DMF was stored in another. The two solutions were added dropwise into the flask at the same speed at $100^{\circ} \mathrm{C}$, then, the mixture was refluxed overnight. After completion of the reaction, the color of the mixture became blackish green with fluorescence. The remained solvent DMF was removed by distillation. 
Then, the resulting mixture was diluted with water and extracted from chloroform $(3 \mathrm{x}$ $50 \mathrm{~mL}$ ). A strong fluorescence component can be separated from the concentrated extracted solution. Then, a yellow crystal was obtained after re-crystallization process. Mp: $280 \sim 282^{\circ} \mathrm{C}$.

${ }^{1} \mathrm{NMR}\left(\mathrm{CDCl}_{3}\right): \quad \delta 3.1(\mathrm{~s}, 6 \mathrm{H}), 3.1 \sim 3.2(\mathrm{t}, 2 \mathrm{H}), 3.35(\mathrm{t}, 2 \mathrm{H}), 3.45(\mathrm{t}, 2 \mathrm{H}), 3.7(\mathrm{t}, 2 \mathrm{H})$, 3.8(t, 2H), $4.2(\mathrm{t}, 2 \mathrm{H}), 4.5(\mathrm{t}, 2 \mathrm{H}), 6.8(\mathrm{~d}, 2 \mathrm{H}), 7.2(\mathrm{~d}, 1 \mathrm{H}), 7.4(\mathrm{~d}, 1 \mathrm{H}), 7.9(\mathrm{~d}, 1 \mathrm{H}), 8.1$ $(\mathrm{d}, 2 \mathrm{H})$.

MS (m/e): 455 (412, 323,280, 207, 162, 148, 132, 91, 77, 45).

Scheme 3 The procedure for the synthesis of the ligand $\mathbf{L}$.

$\mathrm{HOCH}_{2} \mathrm{CH}_{2} \mathrm{OCH}_{2} \mathrm{CH}_{2} \mathrm{OCH}_{2} \mathrm{CH}_{2} \mathrm{OCH}_{2} \mathrm{CH}_{2} \mathrm{OH} \stackrel{\mathrm{PBr}_{3}}{\longrightarrow} \mathrm{BrCH}_{2} \mathrm{CH}_{2} \mathrm{OCH}_{2} \mathrm{CH}_{2} \mathrm{OCH}_{2} \mathrm{CH}_{2} \mathrm{OCH}_{2} \mathrm{CH}_{2} \mathrm{Br}$<smiles>CC(=O)c1cc(O)ccc1O</smiles> 